\title{
Field Study on Prevalence and Risk Factors for Gastrointestinal Nematodes in Selected Herds of Cattle
}

\author{
Aleksandra Balicka-Ramisz ${ }^{1}$, Anna Ramisz ${ }^{2}$, Łukasz Laurans ${ }^{3}$, Marcin Piotrowski ${ }^{4}$ \\ ${ }^{1}$ Department of Biotechnology of Animal Reproduction and Environment Hygiene, West Pomerania University of \\ Technology; Szczecin, Poland, e-mail: abalicka52@gmail.com \\ ${ }^{2}$ Pomeranian Medical University, Szczecin, Poland \\ ${ }^{3}$ Clinic of Infectious Diseases, Hepatology and Liver Transplantation, Pomeranian Medical University str. Arkońska 4, 71-455 \\ Szczecin, Poland \\ ${ }^{4}$ West Pomerania University of Technology; Szczecin, Poland
}

Received on: 10.07.2019; accepted for printing on: 14.10.2019

\begin{abstract}
The purpose of the research is study of the effect of productivity direction and season on cattle contamination with gastrointestinal nematodes.

Materials and methods. Analyzing the criterion of animal husbandry system, two herds of meat cattle of blonde d'aquitaine meat breeds (54 individuals - grazing) of the Limousine breed (53 specimens - rearing without pasture) and two flocks of HolsteinFriesian dairy cattle from three farms (187 - with access to pastures) individuals located in north-western Poland. The research was carried out in 2014-2017. The animals were not dewormed. Attempts for parasitological examinations were collected from January to December from the handpiece or from the bedding immediately after defecation. The study was based on a quantitative method using the McMaster technique, which allowed the number of eggs to be determined in $1 \mathrm{~g}$ of feces.
\end{abstract}

Results and discussion. A high percentage of cattle infection with a mixed infection of GIN was found. The greatest intensity of infection was demonstrated in April, May and June. In these months, the average degree of worming ranged from 58.31 to $92.53 \%$ depending on the type of farm. The lowest level of infection was in winter months: December, January, February. Comparison of the prevalence of invasive endoparasites in dairy and beef cattle showed a higher extensiveness of infection in beef cattle. The increase in the number of eggs was observed along with the increase in the extensiveness of infection in the spring months. During this period, the EPG coefficient ranged from 359-468 eggs/gram. In summer months there was a slight decrease in the number of eggs in the faeces oscillated around 416-325 eggs/gram. Repeated egg expulsion was observed in August. After this period the excretion of eggs decreased. Microclimate factors, especially temperature and atmospheric precipitation, have a huge impact on the spread of helminthosis. Therefore, learning the exact dynamics of infection with endoparasites in an annual cycle has an important practical aspect in the selection of deworming dates.

Keywords: cattle, gastrointestinal nematodes, naturally infection, prevalence.

For citation: Balicka-Ramisz A., Ramisz A., Laurans Ł., Piotrowski M. Field study on prevalence and risk factors for gastrointestinal nematodes in selected herds of cattle. Rossiyskiy parazitologicheskiy zhurnal = Russian Journal of Parasitology. $2019 ; 13$ (4): 11-16. https://doi.org/10.31016/1998-8435-2019-13-4-11-16

( ) Aleksandra Balicka-Ramisz, Anna Ramisz, Łukasz Laurans, Marcin Piotrowski 


\title{
Изучение распространения и факторов риска желудочно-кишечных нематодозов у отдельных стад крупного рогатого скота
}

\author{
Александра Балицка-Рамиш ${ }^{1}$, Анна Рамиш ${ }^{2}$, Лукаш Лауранс ${ }^{3}$, Марцин Пиотровский ${ }^{4}$ \\ ${ }^{1}$ Кафедра биотехнологии репродукции животных и гигиены окружающей среды, Западно-Поморский технический \\ университет, г. Щецин, Польша, e-mail: abalicka52@gmail.com \\ ${ }^{2}$ Поморский медицинский университет, г. Щецин, Польша \\ ${ }^{3}$ Клиника инфекционных заболеваний, гепатологии и трансплантации печени, Поморский медицинский универси- \\ тет, ул. Арконска, 4, 71-455, г. Щецин, Польша \\ ${ }^{4}$ Западно-Поморский технологический университет, г. Щецин, Польша
}

Поступила в редакцию: 10.07.2019; принята в печать: 14.10.2019

\begin{abstract}
Аннотация
Цель исследований: изучение зараженности крупного рогатого скота желудочно-кишечными нематодами в зависимости от направления продуктивности и сезона года.
\end{abstract}

Материалы и методы. Исследования проводили в 2014-2017 гг. в двух стадах мясного крупного рогатого скота (54 гол. выпасающихся и 53 гол. без выпаса) и двух стадах молочного скота из трех ферм (187 гол. выпасающихся), расположенных на северо-западе Польши. Животные не были дегельминтизированы. Пробы фекалий исследовали с января по декабрь количественным методом МакМастера.

Результаты и обсуждение. Установлена высокая зараженность крупного рогатого скота смешанной инвазией, вызванной желудочно-кишечными нематодами. Наибольшая интенсивность заражения была выявлена в апреле, мае и июне. Экстенсивность инвазии варьировала от 58,31 до 92,53\% в зависимости от типа фермы. Низкая зараженность отмечена в зимние месяцы: декабре-феврале. Мясной скот был инвазирован желудочно-кишечными нематодами в большей степени, что, вероятно, связано с тем, что мясной скот выпасают чаще. Увеличение числа яиц в фекалиях наблюдали одновременно с увеличением экстенсивности инвазии в весенние месяцы. В этот период в 1 г фекалий находили 359-468 яиц нематод. В летние месяцы отмечали небольшое уменьшение числа яиц в фекалиях - 416-325 яиц в 1 г фекалий. Повторное снижение числа яиц в фекалиях регистрировали в августе. После этого периода выделение яиц нематод уменьшалось. Температура и атмосферные осадки оказывают огромное влияние на распространение желудочно-кишечных нематодозов. Поэтому изучение динамики заражения эндопаразитами 8 годовом цикле имеет важный практический аспект при выборе сроков дегельминтизации.

Ключевые слова: крупный рогатый скот, желудочно-кишечные нематоды, зараженность, распространение.

Для цитирования: Балицка-Рамиш А., Рамиш А., Лауранс Л., Пиотровский М. Изучение распространения и факторов риска желудочно-кишечных нематодозов у отдельных стад крупного рогатого скота // Российский паразитологический журнал. 2019. T. 13. № 4. C. 11-16. https://doi.org/10.31016/1998-8435-2019-13-4-11-16

\section{Introduction}

Bovine gastro-intestinal nematodes (GIN) are widely distributed throughout almost the entire globe, regardless of climatic conditions. This feature is due to good adaptation to the host of high resistance to diverse geoclimatic and breeding conditions. Gastro-intestinal nematodes are a parasitic disease of great economic importance. Damage caused to cattle breeding is enormous and can contribute to reducing the profitability of breeding. Economic assessment shows that the greatest losses caused by parasites occur in the decline of animal production, and not in their mortality. Losses that cause concern both cattle breeders (increased feed consumption, lower milk yield, lower body weight gains, possible falls of animals), industry (confiscation of carcasses and organs infested by the parasite, poorer quality of products) as well as may affect the consumers themselves (reduced value nutritional products [1,2].

On German farms, losses caused by GIN per year were estimated at EUR 721.38 and Fasciola 
hepatica infections (EUR 565.61) [3]. American farmers, on the other hand, suffer more than USD 2 billion a year, which is manifested by the decrease in milk production costs of meat production [4]. In Mexico, damage caused by endo- and ectoparasites of cattle was estimated at USD 1.41 billion per year per one cow amounted to USD 43.57 [5]. Most European herds of cattle are based on pasture grazing, and therefore there is a risk of losses caused by nematodes. Economic evaluation was preceded by an analysis of the distribution of GIN in cattle in a given region [6,7]. Comprehensive research conducted in European countries: Belgium, Great Britain and Ireland, Germany and Sweden, took into account regional differences in the degree of GIN. These are most often subclinical infections and may still be responsible for production losses [8]. The explanation of cattle infection was explained in different systems in farm management (grazing time, mowing, months of attendance, living conditions and parasitological prophylaxis) [9]. In post-mortem examinations carried out in slaughterhouses in Belgium, the Netherlands and France, nematodes of the gastrointestinal tract were found in 91, 96 and $84 \%$ of beef carcasses tested, with Ostertagia ostertagi being the most frequently found species $[10-12,6]$.

On farms in the northeastern Caucasus where the dynamics of GIN infections were carried out, calves showed that the maximum infection occurred at the end of summer and early autumn. This is evidence that the infection occurs most often during the summer in this region. A known species [13].

Studies on the dependence of the degree of infection and the type of cattle endoparasites and climatic and meteorological conditions in the steppe, semi-arid and desert areas of the region were conducted in the area of Western Kazakhstan. In total, 29 farms were included in the survey, including 8 in the steppe zone, 12 in the sand zone, 9 in the desert in the annual cycle. The seasonality of the GIN infection has been demonstrated during the year. The degree of infection with gut nematodes in winter and before grazing was the smallest and amounted to zones: steppe, desert and desert zones $-27.6 \%$ respectively; 14.4 and $11.4 \%$, and in the autumn, at the end of the grazing season, the highest invasiveness was recorded - 44.3; 33.8 and 27.2\% [14]. The degree of infection with GIN eggs in Poland, depending on the region, ranged between 46.5$87.0 \%$, native breeds depending on the region 44.3 ; 33.8 and $27.2 \%$ [15]. However, the average frequency of gastrointestinal parasites in heifers imported to Poland was $83.96 \%$ [16]. In addition to serious economic losses, they also cause sanitary problems. Antiparasitic preparations are often given without taking into account regional variables. The research shows that the dynamics of parasite infection in addition to production practices is influenced by seasonal weather patterns, pasture pollution of eggs and larvae of endoparasites that change during the pasture season. Noodles infected with nematodes can excrete up to 2,000 eggs per day in a gram of stool. Adult cattle in Polish conditions staying on a pasture in a system of round-the-clock grazing issued about $43 \mathrm{~kg}$ of feces, with a frequency of defecation 10-18 times a day $[17,18]$.

The outages of these animals lying in the pasture cause various effects both for plants and animals. The plant provides valuable manure contributing to the growth of grass by activating the soil bacterial flora. They are also an unfavorable factor increasing the risk of parasite infection. To infection with parasites, it most often occurs in the pasture, where invasive forms develop on the stems of grasses. Larvae present in the ground soil layer have greater survival, because there are more favorable conditions for survival. (high humidity and less sunlight). Researchers from Liverpool, through the analysis of collective milk samples from ruminant herds in England and Wales, identified factors that increase the risk of infection listed in the tables below (table 1,2) changing during the pasture season.

Table 1

Factors that increase the risk of parasitism

\begin{tabular}{|c|c|}
\hline \multicolumn{2}{|c|}{ FACTORS INCREASING THE RISK OF INFECTION } \\
\hline CLIMATE FACTORS & PHYSICAL FACTORS \\
\hline $\begin{array}{l}\text { Rainy days in summer } \\
\text { (from July to October) }\end{array}$ & $\begin{array}{c}\text { The size of pas- } \\
\text { tures on the farm }\end{array}$ \\
\hline mild winters & Low-class soils \\
\hline Chilly spring (May and June) & $\begin{array}{l}\text { Presence and number } \\
\text { of cattle on the farm }\end{array}$ \\
\hline A warm summer & \\
\hline
\end{tabular}

Table 2

Factors that reduce the risk of parasitism

\begin{tabular}{|c|c|}
\hline \multicolumn{2}{|c|}{ FACTORS INCREASING THE RISK OF INFECTION } \\
\hline CLIMATE FACTORS & PHYSICAL FACTORS \\
\hline $\begin{array}{c}\text { Gentle and early spring } \\
\text { (February-April) }\end{array}$ & Slope of the area \\
\hline Cool summer (July-October) & The size of the cattle herd \\
\hline $\begin{array}{c}\text { Mistrict winter (November- } \\
\text { January and February-April) }\end{array}$ & Soil alkalinity \\
\hline
\end{tabular}


More than 20 species of nematodes with different degrees of cognition are described in the world literature. In Poland, the GIN belonging to the two families Trichostrongylidae (Trichostrongylus, Ostertagia, Cooperia, Haemonchus and Nematodirus), and Strongyloidae (Strongyloides) are important. Knowledge of dynamics in the annual cycle of infection with cattle nematodes allows to predict the possibility of parasites appearing at any moment of the year, to plan and implement appropriate time for parasitological prophylaxis.

There is no information on the dynamics of cattle nematode infection in moderate climate.

The present study was therefore conducted in order to obtain information on epidemiology of GIN in cattle for the West Pomeranian region of Poland.

\section{Materials and methods}

Individual farms where own research was conducted represented a diversified cast and production profile. Analyzing the criterion of animal husbandry system, two herds of meat cattle of blonde d'aquitaine meat breeds (54 individuals - grazing) of the Limousine breed (53 specimens - rearing without pasture) and two flocks of Holstein-Friesian dairy cattle from three farms (187 - with access to pastures) individuals located in north-western Poland. The research was carried out in 2014-2017. The animals were not dewormed. Attempts for parasitological examinations were collected from January to December from the handpiece or from the bedding immediately after defecation. The study was based on a quantitative method (Fecal Egg Counts - FEC) using the McMaster technique, which allowed the number of eggs to be determined in $1 \mathrm{~g}$ of feces (EPG factor) [19].

\section{Results and discussion}

The dynamics of the course of the infection were similar in all the studied groups. In the analyzed flocks, a high percentage of cattle infection with a mixed infection of GIN was found. The greatest intensity of infection was demonstrated in April, May and June. In these months, the average degree of worming ranged from 58.31 to $92.53 \%$ depending on the type of farm. The lowest level of infection was in winter months: December, January, February (Fig. 1). Comparison of the prevalence of invasive endoparasites in dairy and beef cattle showed a higher extensiveness of infection in beef cattle. Such a result of the study is probably a reflection of the fact that meat cattle uses grazing more often, which contributes to the infection of the above-mentioned parasites $[20,21]$.

The dominant role of GIN in grazing animals is confirmed by other studies conducted in Poland and in neighboring countries. In Western Pomerania, Pilarczyk et al. demonstrated the infection of this group of non-nifty in large herds, at the level of $42 \%$. In addition, they found more than $50 \%$ extensiveness of the infection of nematodes from the Trichostrongylidae family in animals imported to Poland from Germany, France and the Czech Republic [22]. In regions with a comparable climate in Germany, the prevalence of GIN was confirmed depending on the region of the study in the range from 15.9 to $42,0 \%$ imported to Poland from Germany, France and the Czech Republic [23]. Monitoring in five German herds of dairy cows showed a generally high degree of worming over 70\%, including Eimeria, GIN and F. hepatica. The severity of the infection was related to the strong impacts of the regional and seasonal microclimate. The test results were not confirmed during veterinary visits to the farm [7]. In Belgium, the occurrence of GIN in cattle grazed on pastures was found in $64 \%$ of samples [24], in the Netherlands, infection was confirmed in $96 \%$ of individuals [25] and in Italy, cattle imported from France, 59\% [26].

The increase in the number of eggs was observed along with the increase in the extensiveness of infection in the spring months. During this period, the EPG coefficient ranged from 359468 eggs/gram (Fig. 2). In summer months there was a slight decrease in the number of eggs in the faeces oscillated around 416-325 eggs/gram. Repeated egg expulsion was observed in August. After this period, the excretion of eggs decreased.

In spring period, the infection of GIN in cattle is observed. Spring rise, in which the rapid growth of the larvae dormant occurs. These processes are influenced by both climatic factors (mainly related to temperature and humidity), as well as the infected animal itself (age, decline in immunity and condition, anemia, hormonal regulation related to pregnancies, lactations and the location of the parasite). After this period, the excretion of eggs decreased [27]. 


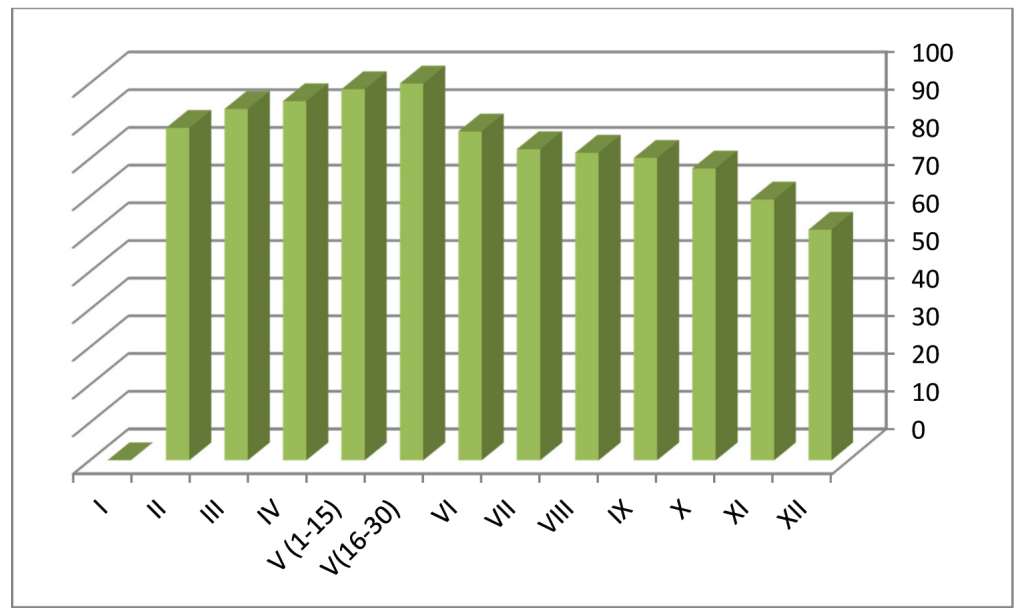

Explanation: Vertical axis - prevalence (\%), Horizontal axis - months

Fig. 1. Prevalence of GIN infection in cattle in an annual cycle

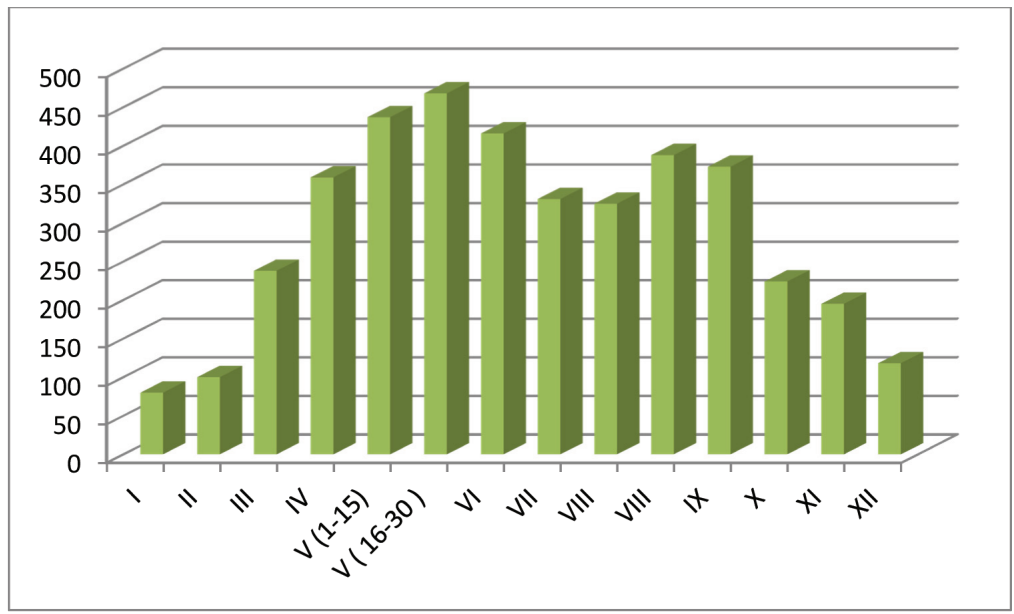

Explanation: Vertical axis - intensity of infection, Horizontal axis - months

Fig. 2. Intensity (EPG) of infection of GIN in cattle in an annual cycle

\section{Conclusions}

Microclimate factors, especially temperature and atmospheric precipitation, have a huge impact on the spread of helminthosis. Therefore, learning the exact dynamics of infection with endoparasites in an annual cycle has an important practical aspect in the selection of deworming dates.

\section{References}

1. Ravine N., Bareille A., Lehebel A., Ponnau C., Chartier A., Chauvin A. Change in milk production after treatment against gastrointestinal nematodes according to grazing history, parasitological and production-based indicators in adult dairy cows. Vet. Parasitol. 2014; 201(1-2): 95-109.
2. Sanchez J., Dohoo J., Carrier J., Luc DesC^oteaux. A meta-analysis of the milk-production responseafter anthelmintic treatment in naturally infected adult dairy cows. Preventive Veterinary Medicine. 2004; 63: 237-256.

3. Fanke J., Charlier J., Steppin T., von Samson-Himmelstjerna G., Vercruysse J., Demeler J. Economic assessment of Ostertagia ostertagi and Fasciola hepatica infections in dairy cattle herds in Germany using Paracalc. Vet. Parasitol. 2017; 240: 39-48. https://doi.org/10.1016/j.vetpar.2017.03.018.

4. Zarlenga D. S., Chute M. B., Gasbarre L. C., Boyd P. C. A multiplex PCR assay for differentiating economically important gastrointestinal nematodes of cattle. Vet. Parasitol. 2001; 97: 199-209. 
5. Hidalgo M. A. G., Pineda L., Olvera E., Ortiz R. M., Cuellar A., Galinado E. Potential economic impact assessment for cattle parasites in Mexico. Rev. Mex. Cienc Pecu. 2017;8(1): 61-74 http://dx.doi. org/10.22319/rmcp.v8i1.4305.

6. Blanco-Penedo I., Höglund J., Fall N., Emanuelson U. Exposure to pasture borne nematodes affects individual milk yield in Swedish dairy herds. Vet. Parasitol. 2012; 18: 93-98. https://doi.org/10.1016/j. vetpar.2012.02.024

7. Gillandt K., Stracke J., Hohnholz T., Waßmuth R. Kemper N. A Field Study on the Prevalence of and Risk Factors for Endoparasites in Beef Suckler Cow Herds in Germany. Agriculture. 2018; 8(9): 132137. https://doi.org/10.3390/agriculture8090132 .

8. Charlier J., Höglund J., Samson-Himmelstjerna G.,. Dorny D., Vercruysse J. Gastrointestinal nematode infections in adult dairy cattle: impact on production, diagnosis and control. Vet. Parasitol. 2009; 164: 70-79.

9. Bennemaa S. C., Vercruyssea J., Morganb E., Staffordc K., Höglundd J., Demelere J., von SamsonHimmelstjernae J., Charliera J. Epidemiology and risk factors for exposure to gastro intestinal nematodes in dairy herds in northwestern Europe. Vet. Parasitol. 2010; 173: 247-254.

10. Agneessens J., Dorny P., Hollanders W., Claerebout E. Vercruysse J. Epidemiological observations on gastrointestinal nematode infections in grazing cow-calf pairs in Belgium. Vet. Parasitol. 1997; 69: 65-75.

11. Borgsteedea F., Tibbena J., Cornelissena J., Agneessensb J., Gaasenbeek C. Nematode parasites of adult dairy cattle in the Netherlands. Vet. Parasitol. 2000; 89: 287-296.

12. Charlier J., De Waele V., Ducheyne E., van der Voort M., Vande Velde F., Claerebout E. Decision making on helminths in cattle: diagnostics, economics and human behaviour. Irish Veterinary Journal. 2016; 69: 14-19. 2731. https://doi. org/10.1186/s13620-016-0073-6.

13. Bajsarova Z. T., Ajshanov S. T. Dynamics of infestation of calves with the major nematode species in conditions of the northeastern Caucasus. Russian Journal of Parasitology. 2015; 2: 32-37.

14. Karmaliyev R. S., Akhmedenov K. M., Sidikhov B. M., Aytuganov B. E., Usenov Zh. T., Ertleuova B. O., Gabdullin D. E., Aliyev E. M. Helminths infection of cattle depending on natural climatic conditions of West Kazakhstan region. Rossiyskiy parazitologicheskiy zhurnal = Russian Journal of Parasitology. 2019; 13(1): 16-22. https://doi. org/10.31016/1998-8435-2019-13-1-16-22.

15. Piekarska J., Płoneczka-Janeczk K., KantykaM., KuczajM., Gorczykowski M., Janeczko K. Gas- trointestinal nematodes in grazing dairy cattle from small and medium-sized farms in southern Poland. Vet. Parasitol. 2013; 198: 250-253.

16. Pilarczyk P., Balicka-Ramisz A., Kozak W. Ramisz A. Occurrence of endoparasites in heifers imported to Poland from the Netherlands. Archiv Tierzucht. 2009; 52 (3): 265-271.

17. Nowakowski P., Popiołek M., Dobicki A., Troska K., Coimbra Ribeiro S., Serreau Y., Pora K., Wojciechowska M. Dynamika inwazji nicieni żołdkowo-jelitowych bydła mięsnego wypasanego na terenach trawiastych parku narodowego „ujście warty. Acta Sci. Pol., Medicina Veterinaria. 2007; 6(3): 37-47 (in Polish).

18. http://www.deliver-project.eu/uploads/Guidelines/NewsLetter_Polish.pdf

19. Eckert J., Friedhoff K. T., Zahner H., Deplazes P. Lehrbuch der Parasitologiefürdie Tiermedizin, EnkeVerlagSuuttgart, 2005.

20. Bellet C., Green M. J., Bradley A. J., Kaler J. A longitudinal study of gastrointestinal parasites in English dairy farms. Practices and factors associated with first lactation heifer exposure to Ostertagia ostertagi on pasture. J. Dairy Sci. 2018; 101: 537-546.

21. Tomczuk K., Szczepaniak K., Demkowska-Kutrzepa M., Roczeń-Karczmarz M., Junkuszew A., Gruszecki T., Drozd L., Karpiński M., Studzińska M. Occurrence of internal parasites in cattle in various management systems in South-East Poland. Med. Weter. 2018; 74 (8): 501-506. https:// dx.doi.org/10.21521/mw.6105.

22. Pilarczyk B., Balicka-Ramisz A., Kozak W. Ramisz A. Occurrence of endoparasites in heifers imported to Poland from the Netherlands. Archiv Tierzucht. 2009; 52(3): 265-271.

23. Kemper N., Henze C. Effects of pastures' re-wetting on endoparasites in cattle in northern Germany. Vet. Parasitol. 2009; 161: 302-306.

24. Agneessens J., Claerebout E., Dorny P., Borgsteede F. H. M., Vercruysse J. Nematode parasitism in adult dairy cows in Belgium. Vet. Parasitol. 2000; 90: 83-92.

25. Borgsteede F. H. M., Tibben J., Cornelissen J. B. W. J., Agneessens J., Gaasen- beek C. P. H. Nematode parasites of adult dairy cattle in the Netherlands. Vet. Parasitol. 2000; 89: 287-296.

26. Stancampiano L., Corradini D., Bulgarelli M., Micagni G., Battelli G. Parasites of the digestive tract in beef cattle imported from France to Italy. Parassitologia. 2007; 49: 101-106.

27. Armour J., Jennings F. W., Urguhart G. M. Inhibition of Ostertagia at the early fourth larval stage I. The seasonal incidence. Res. Vet. Sci. 2007; 232-237. 